\title{
Maturational Regulation of Globotriaosylceramide, the Shiga-like Toxin 1 Receptor, in Cultured Human Gut Epithelial Cells
}

\author{
Mary S. Jacewicz, ${ }^{*}$ David W. K. Acheson, ${ }^{*}$ Munir Mobassaleh, ${ }^{*}$ Arthur Donohue-Rolfe, ${ }^{*}$ K. A. Balasubramanian, ${ }^{\$}$ \\ and Gerald T. Keusch* \\ Divisions of *Geographic Medicine and Infectious Diseases and ${ }^{\ddagger}$ Pediatric Gastroenterology and Nutrition, Tupper Research Institute, \\ New England Medical Center, Boston, Massachusetts 02111; and the ${ }^{8}$ Wellcome Research Unit, Christian Medical College, \\ Vellore, S. India
}

\begin{abstract}
Differentiated villus intestinal epithelial cells express globotriaosylceramide, the Shiga-like toxin 1 (SLT-1) receptor, and are sensitive to toxin-mediated cytotoxicity, whereas undifferentiated crypt cells neither express $\mathrm{Gb3}$ nor respond to toxin. To investigate if SLT-1 receptors are maturationally regulated in human intestinal cells, we examined the effect of butyrate, a known transcriptional regulator of differentiation genes in many cell types, using cultured colonic cancer-derived epithelial cell lines. Exposure to butyrate increased villus cell marker enzymes such as alkaline phosphatase, sucrase, and lactase, expression of toxin receptors, and sensitivity to SLT-1 in villus-like CaCo-2A and HT-29 cells. These effects were reversibly inhibited by preincubation of CaCo-2A cells with actinomycin $D$ or cycloheximide. Butyrate-treated $\mathrm{CaCo}-2 \mathrm{~A}$ cells unable to bind fluoresceinated SLT-1 B subunit were undifferentiated as assessed by alkaline phosphatase activity. HT-29 cells induced to differentiate by another signal, glucose deprivation, upregulated receptor content and response to toxin. Crypt-like T-84 cells responded to butyrate with a modest increase in alkaline phosphatase and toxin binding, but no induction of sucrase or lactase, and no change in sensitivity to toxin. The results demonstrate that expression of SLT-1 toxin receptors and toxin sensitivity are coregulated with cellular differentiation in cultured intestinal cells. ( $J$. Clin. Invest. 1995. 96:13281335.) Key words: bacterial toxins • receptors • cells, cultured $\cdot$ glycolipids $\cdot$ differentiation
\end{abstract}

\section{Introduction}

Shiga toxin (STX) ${ }^{1}$ is the prototype of an enlarging family of highly potent protein exotoxins produced by Shigella dysenter-

This study was presented in part at the 33rd Interscience Conference on Antimicrobial Agents and Chemotherapy, American Society for Microbiology, in New Orleans on 17-20 October 1993.

Address correspondence to Gerald T. Keusch, M.D., New England Medical Center, 750 Washington St., Box 041, Boston, MA 02111. Phone: 617-636-7001; FAX: 617-636-5292.

Received for publication 29 December 1994 and accepted in revised form 25 May 1995.

1. Abbreviations used in this paper: D-MEM, Dulbecco's MEM; EIA enzyme immunoassay; Gb3, globotriaosylceramide; Gb4, globotetraosylceramide; SLT, Shiga-like toxin; STX, Shiga toxin.

J. Clin. Invest.

(C) The American Society for Clinical Investigation, Inc.

0021-9738/95/09/1328/08 \$2.00

Volume 96, September 1995, 1328-1335 iae type 1, certain serotypes of Escherichia coli (1, 2), and uncommonly other organisms such as Citrobacter freundii (3). The family includes STX itself, the $E$. coli-encoded Shiga-like toxin-1 (SLT-1), SLT-2, SLT-2e (the variant toxin involved in porcine edema disease), and additional variants such as SLT$2 c$ from human isolates. These toxins are structurally similar heterodimers composed of one enzymatically active A subunit $\left(M_{\mathrm{r}} \approx 32,000\right)$ that irreversibly inhibits protein synthesis by means of its $N$-glycosidase activity on a single adenine in the 28S rRNA of the 60S ribosomal subunit (4) and 5 B subunits $\left(M_{\mathrm{r}}=7,000-8,000\right)$. The B-subunit pentamer mediates toxin binding to a galactose- $\alpha 1 \rightarrow 4$-galactose disaccharide containing neutral glycolipid receptor, including globotriaosylceramide (Gb3) in the case of STX, SLT-1, or SLT-2 $(5,6)$, and globotetraosylceramide (Gb4) for SLT-2e (7).

The precise role of these toxins, which cause net fluid secretion in rabbit small bowel, in pathogenesis of intestinal disease associated with toxin-producing bacteria has yet to be established. Our laboratory has reported that the enterotoxic effect of STX in rabbit intestine is due to a selective action on villus, but not crypt, cells ( 8 ). Toxin inhibition of protein synthesis in villus cells is associated with reduced sodium absorption and increased net fluid secretion. The basis for this selectivity appears to be differential expression of $\mathrm{Gb3}$ in villus but not crypt cells.

Crypt cells are relatively undifferentiated proliferating cells which actively secrete chloride by a cyclic nucleotide-dependent mechanism. As they migrate up the villus, however, intestinal cells differentiate and acquire the enzymatic and morphological characteristics of the mature villus epithelium (9). The present experiments were designed to determine whether changes in sensitivity to toxin of cultured intestinal cell lines are associated with differentiation. To accomplish this, we exposed three intestinal cell lines derived from human colon carcinomas $(\mathrm{CaCo}-$ 2A, HT-29, and T-84) to the short chain fatty acid sodium butyrate, normally found in the intestinal lumen, which induces differentiation of many cells in culture (10-15), and measured the effects on differentiation marker enzymes, the content of $\mathrm{Gb3}$, and the binding and cytotoxic response to SLT-1.

\section{Methods}

Cells

CaCo-2A cells which develop villus-like properties during growth to confluence were provided by Dr. Douglas Jefferson (Gastrointestinal Research Center Cell Culture Core Laboratory at New England Medical Center). HT-29 cells, which also differentiate into villus-like cells in culture, and T-84 cells, which possess crypt-like chloride secretory properties, were purchased from the American Type Culture Collection (Rockville, MD). CaCo-2A and HT-29 cells were maintained in Dulbecco's MEM (D-MEM; high glucose) supplemented with $10 \%$ (vol/ 


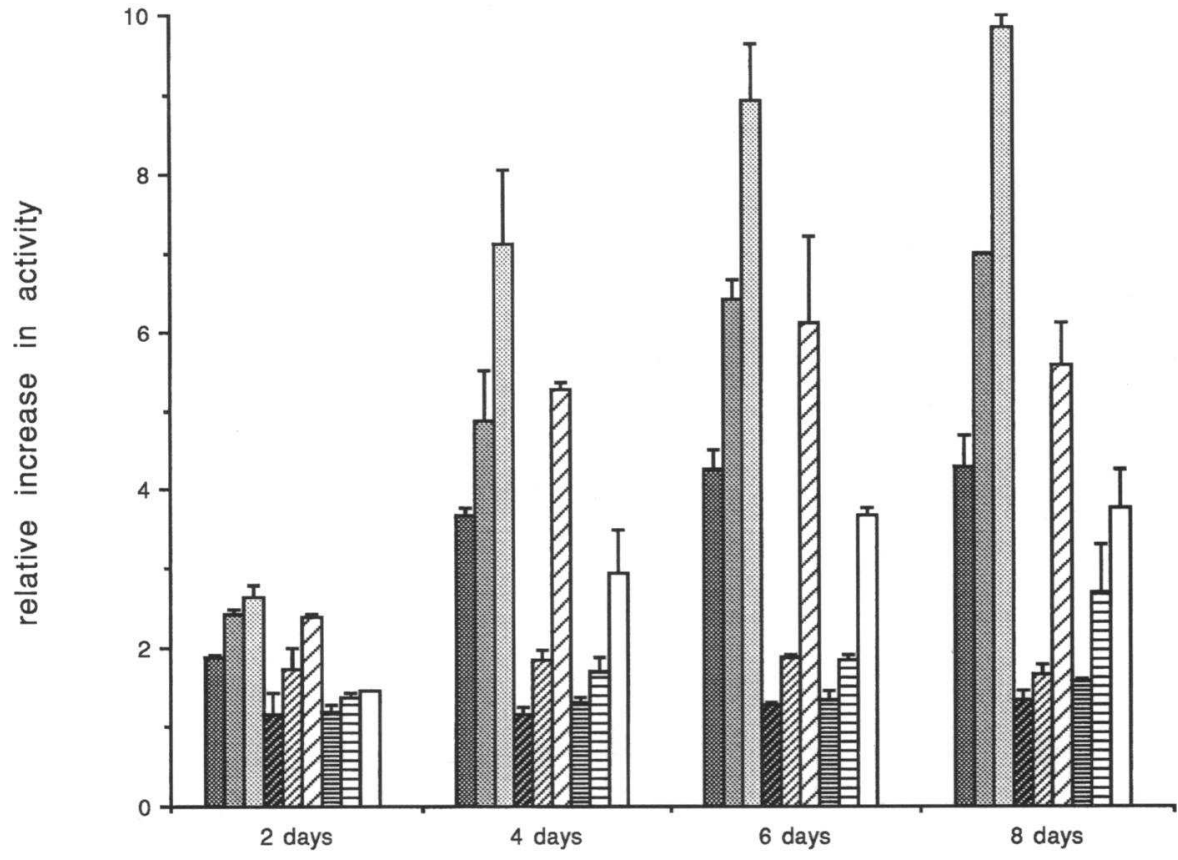

duration of treatment
Figure 1. Effects of increasing duration of exposure of cell lines to butyrate on expression of alkaline phosphatase activity. In each group of nine bars, the three bars to the left show the results obtained with $\mathrm{CaCo}-2 \mathrm{~A}$ cells, the middle group of three bars represents HT-29 cells, and the group on the right shows T-84 cells. In each group of three, the darkest bar represents exposure to $0.5 \mathrm{mM}$ butyrate, the medium bar represents exposure to $1.0 \mathrm{mM}$ butyrate, and the lightest bar represents exposure to $2.0 \mathrm{mM}$ butyrate. The duration of incubation with butyrate is shown along the ordinate. One standard deviation is indicated in each bar. vol) fetal bovine serum (FBS), $100 \mathrm{U} / \mathrm{ml}$ penicillin, $100 \mu \mathrm{g} / \mathrm{ml}$ streptomycin, $1 \mathrm{mM}$ pyruvate, and $25 \mathrm{mM}$ Hepes. T- 84 cells were maintained in 1:1 (vol/vol) D-MEM (low glucose)/F12 nutrient mixture supplemented with 6\% FBS and other additives as above. All media and supplements were from GIBCO BRL (Gaithersburg, MD).

Cells were grown in $75-\mathrm{cm}^{2}$ flasks at $37^{\circ} \mathrm{C}$ in $5 \% \mathrm{CO}_{2}$, fed at 2-d intervals, and passaged weekly. Stock cells were trypsinized, suspended at $10^{5}$ cells $/ \mathrm{ml}$ in medium, and $200 \mu \mathrm{l}$ was seeded per well in 96-well microtiter plates. After $48 \mathrm{~h}$ at $37^{\circ} \mathrm{C}$, medium was replaced with medium containing $0,0.5,1$, or $2 \mathrm{mM}$ sodium butyrate. Cells were incubated for an additional 2, 4, 6, or $8 \mathrm{~d}$, with medium changes at 2-d intervals. In some experiments $\mathrm{CaCo}-2 \mathrm{~A}$ cells were pretreated for $24 \mathrm{~h}$ with either actinomycin D, $0.5 \mu \mathrm{g} / \mathrm{ml}$, or cycloheximide, $100 \mu \mathrm{g} / \mathrm{ml}$ (both from Sigma Immunochemicals, St. Louis, MO), before exposure to butyrate. The cell count in representative wells was determined by microscopy in a hemocytometer as described (5). For some binding experiments, cells were prefixed with $1 \%$ glutaraldehyde in PBS and washed with PBS.

\section{Toxin purification and labeling}

SLT-1 was purified from sonic lysates of $E$. coli HB101 lysogenized with bacteriophage H19B as reported previously (16) and was labeled with ${ }^{125} \mathrm{I}$ by a modification of the chloramine $\mathrm{T}$ method, which does not alter its specific activity (17). Recombinant SLT-1 B was purified from Vibrio cholerae $0395 \mathrm{N1}$ (pSBC32) (18) and labeled with fluorescein isothiocyanate (FITC) by incubation of $2 \mathrm{mg} / \mathrm{ml}$ subunit in $0.1 \mathrm{M}$ $\mathrm{Na}_{2} \mathrm{CO}_{3}, \mathrm{pH} 9.0$, with $50 \mu \mathrm{l}$ FITC $(1 \mathrm{mg} / \mathrm{ml}$ in DMSO $)$ overnight at $4^{\circ} \mathrm{C}$ in the dark. Labeled SLT-1 B was separated from free dye by Sephadex G25 chromatography and stored at $4^{\circ} \mathrm{C}$ in a light-proof container.

\section{Cytotoxicity assay}

Cytotoxicity was assessed as inhibition of protein synthesis as described previously (19). Cells were treated for $3 \mathrm{~h}$ with 10 -fold dilutions of SLT-1 in medium, followed by $30 \mathrm{~min}$ in medium containing $1 \mathrm{mCi} /$ $\left.100 \mathrm{ml} \mathrm{[}{ }^{3} \mathrm{H}\right]$ leucine. Incorporation of label into TCA-precipitable material was then measured.

\section{Toxin-binding assays}

Toxin binding was assessed by three different methods: $(a)$ binding of ${ }^{125} \mathrm{I}-\mathrm{SLT}-1$ for $1 \mathrm{~h}$ at $4^{\circ} \mathrm{C}$ as described previously $(17) ;(b)$ an enzyme immunoassay (EIA) method using glutaraldehyde-fixed cells; and (c) binding of FITC-SLT-1 B monitored by fluorescence microscopy. EIA was performed at room temperature, and samples were washed five times with PBS after each step. Cells were blocked for $1 \mathrm{~h}$ with $200 \mu \mathrm{l}$ of $3 \%$ gelatin in PBS, incubated for $1 \mathrm{~h}$ with $200 \mu \mathrm{l}$ of serial 10 -fold dilutions of SLT-1, and then successively with polyclonal rabbit antiSLT-1 serum diluted 1:5,000, goat anti-rabbit IgG-HRP conjugate (Sigma Immunochemicals), and $50 \mu 1 /$ well of 3,3',5,5'-tetramethylbenzidine substrate, $100 \mu \mathrm{g} / \mathrm{ml}$ in $0.1 \mathrm{M}$ citrate-acetate buffer, $\mathrm{pH} 5.5$, containing $155 \mu \mathrm{l} 3 \% \mathrm{H}_{2} \mathrm{O}_{2}$ per $100 \mathrm{ml}$ of solution. The reaction was stopped after $15 \mathrm{~min}$ by addition of $50 \mu \mathrm{l}$ of $1 \mathrm{M} \mathrm{H}_{2} \mathrm{SO}_{4}$ and the samples were read at $\mathrm{A}_{450}$. For fluorescence microscopy, cells were grown on 16well Lab-Tek chamber slides (Nunc, Roskilde, Denmark) under various conditions, washed and fixed with $4 \%$ paraformaldehyde in PBS, and incubated for $1 \mathrm{~h}$ with $50 \mu \mathrm{l}$ FITC-SLT-1 B (1:50 dilution in culture medium) in the dark at room temperature. The upper portion of the wells was removed and the slides were washed extensively with PBS/ $0.1 \%$ BSA and examined by fluorescence microscopy.

\section{Fluorescence-activated cell sorting}

CaCo-2A cells exposed to $1 \mathrm{mM}$ butyrate for $4 \mathrm{~d}$ were trypsinized, suspended at $10^{7}$ cells $/ \mathrm{ml}$ in medium, and $1 \mathrm{ml}$ was incubated with 100 $\mu \mathrm{l}$ of FITC-SLT-1 B for $1 \mathrm{~h}$ at $4^{\circ} \mathrm{C}$ with shaking in the dark. After washing five times, cells were resuspended in $2 \mathrm{ml}$ of medium at $4^{\circ} \mathrm{C}$ containing $1 \%$ FBS and subjected to FACS ${ }^{\oplus}$ on a cell sorter (Epics 541; Coulter Corp., Epics Division, Hialeah, FL). Both populations of cells were counted, suspended in alkaline phosphatase buffer (below) at $5 \times 10^{5} \mathrm{cells} / \mathrm{ml}$, and $100 \mu \mathrm{l}$ of each suspension was assayed for alkaline phosphatase activity (below) in triplicate.

\section{Enzyme assays}

Alkaline phosphatase. Cell monolayers were washed twice with PBS, and $100 \mu \mathrm{l} p$-nitrophenyl phosphate $(1 \mathrm{mg} / \mathrm{ml}$ in $100 \mathrm{mM}$ Tris $/ \mathrm{NaCl}$ 

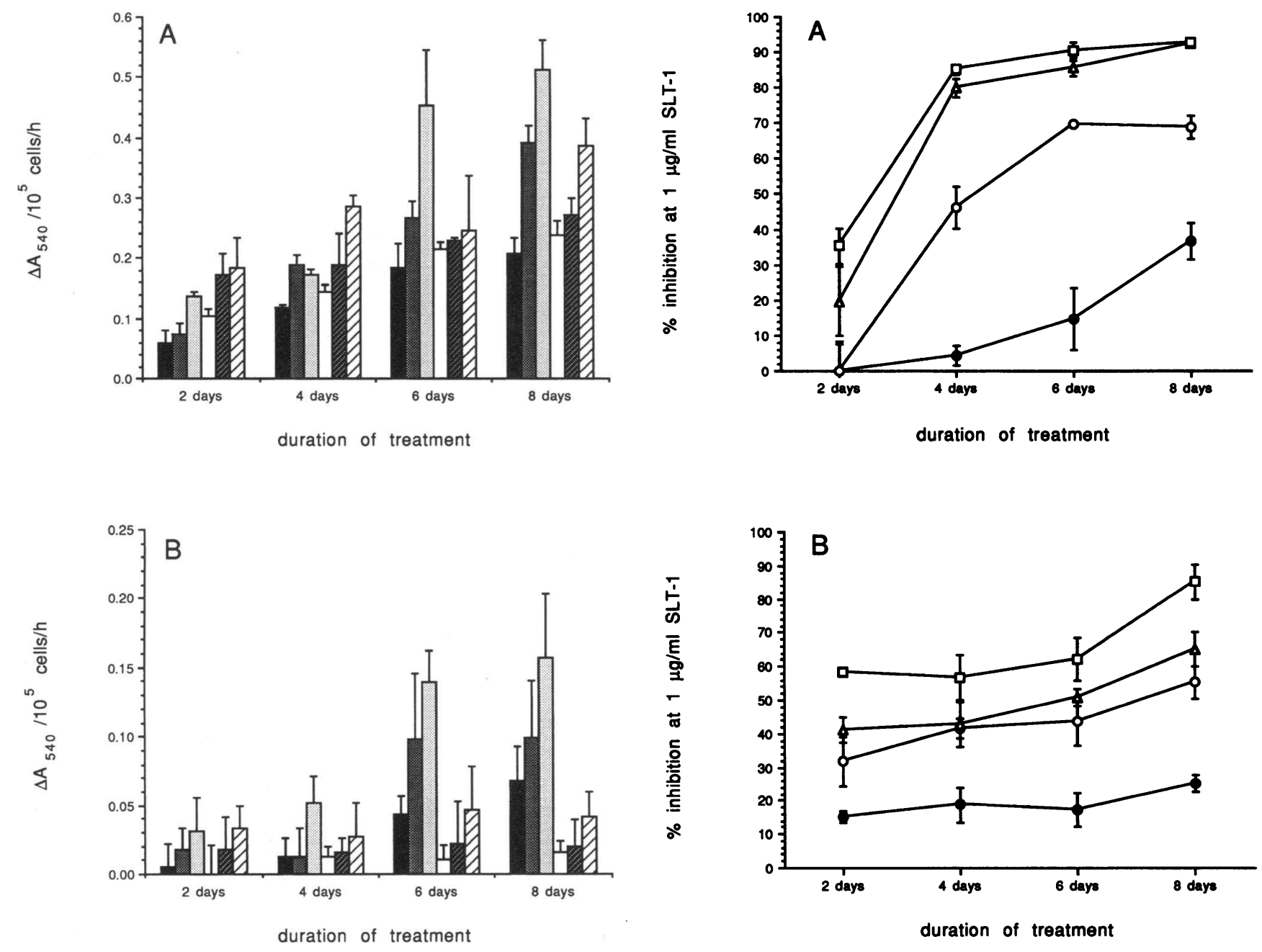

Figure 2. Induction of sucrase $(A)$ and lactase $(B)$ by butyrate in CaCo$2 \mathrm{~A}$ (the three bars to the left in each group) and HT-29 cells (the three bars to the right in each group). The black bar represents $\mathrm{CaCo}-2 \mathrm{~A}$ cells incubated in the absence of butyrate, the dark stippled bar represents exposure of CaCo- $2 \mathrm{~A}$ cells to $0.5 \mathrm{mM}$ butyrate, and the light stippled bar represents exposure to $2.0 \mathrm{mM}$ butyrate. The open bar represents HT-29 cells incubated in the absence of butyrate, the dark hatched bar represents exposure of HT-29 cells to $0.5 \mathrm{mM}$ butyrate, and the light hatched bar shows the exposure to $2.0 \mathrm{mM}$ butyrate. One standard deviation is indicated in each bar.

buffer, $\mathrm{pH} 9.5$, containing $5 \mathrm{mM} \mathrm{MgCl}{ }_{2}$ ) was added to each well. After incubation for $10 \mathrm{~min}$ at room temperature, $\mathrm{A}_{405}$ was measured against cells without substrate. Activity was expressed as the relative increase in $A_{405}$ compared with the same number of cells incubated for the same time without butyrate.

Sucrase and lactase. Monolayers were washed as above, and $50 \mu \mathrm{l}$ $0.62 \mathrm{M}$ sucrose or lactose in $0.1 \mathrm{M} \mathrm{KPO}_{4}$ buffer, $\mathrm{pH} 6.0$, was added to each well, and cells were incubated at $37^{\circ} \mathrm{C}$ for $30 \mathrm{~min}$ (sucrase) or 3 h (lactase). Liberated glucose was detected by a modification of the method of Messer and Dahlqvist (20) using $50 \mu$ l of peroxidase/glucose oxidase reagent $(0.01 \% o$-dianisidine di- $\mathrm{HCl}, 0.001 \%$ horseradish peroxidase [wt/vol] in $0.5 \mathrm{M} \mathrm{NaPO}_{4}$ buffer, pH 6.0, containing enough glucose oxidase to give an $\mathrm{OD}_{540}$ of $0.4-0.5$ for a $4-\mu \mathrm{g}$ glucose standard). Samples were incubated at room temperature for $10 \mathrm{~min}$, the reaction was terminated by addition of $100 \mu \mathrm{l} 50 \% \mathrm{H}_{2} \mathrm{SO}_{4}$, and absorbance was measured at $540 \mathrm{~nm}$ against cells treated with peroxidase/ glucose oxidase reagent but no disaccharide substrate. Activity was

Figure 3. Effect of butyrate concentration and duration of exposure of CaCo-2A cells $(A)$ and HT-29 cells $(B)$ on the inhibition of protein synthesis resulting from incubation with $1 \mu \mathrm{g} / \mathrm{ml}$ of SLT-1. The black circles represent control cells (no butyrate exposure), open circles represent exposure to $0.5 \mathrm{mM}$ butyrate, open triangles show exposure to 1 $\mathrm{mM}$ butyrate, and the open squares show exposure to $2 \mathrm{mM}$ butyrate. One standard deviation is indicated for each data point.

expressed as the change in $A_{540}$ of treated cells compared with the same number of cells incubated for the same length of time without butyrate.

\section{Determination of glycolipid content of cells}

Glycolipids were extracted and measured from scraped cells as reported previously (21). Briefly, lipids were extracted by sonication in chloroform/methanol (2:1) at $55^{\circ} \mathrm{C}$ for $15 \mathrm{~min}$ and separated by Folch partition. Lower phase lipids were purified on a Unisil column (Clarkson Chemical Co., Inc., Williamsport, PA) and phospholipids were hydrolyzed with methanolic $\mathrm{NaOH}$. Samples were benzoylated and assayed by quantitative HPLC on a pellicular Zipax column (DuPont, Wilmington, DE) with a linear $2-42 \%$ gradient of $46 \%$ dioxane in hexane diluted into hexane. Eluted peaks were detected by ultraviolet absorption at 230 $\mathrm{nm}$ and were analyzed on a Beckman HPLC with System Gold software (Beckman Instruments, Inc., San Ramon, CA).

\section{Statistical analysis}

Data are expressed as mean $\pm \mathrm{SD}$. Where appropriate, the differences in the mean values of treated versus untreated cells were compared for significance using a two-tailed Student's $t$ test for unpaired samples. Differences were considered significant if $P$ was $<0.01$. 

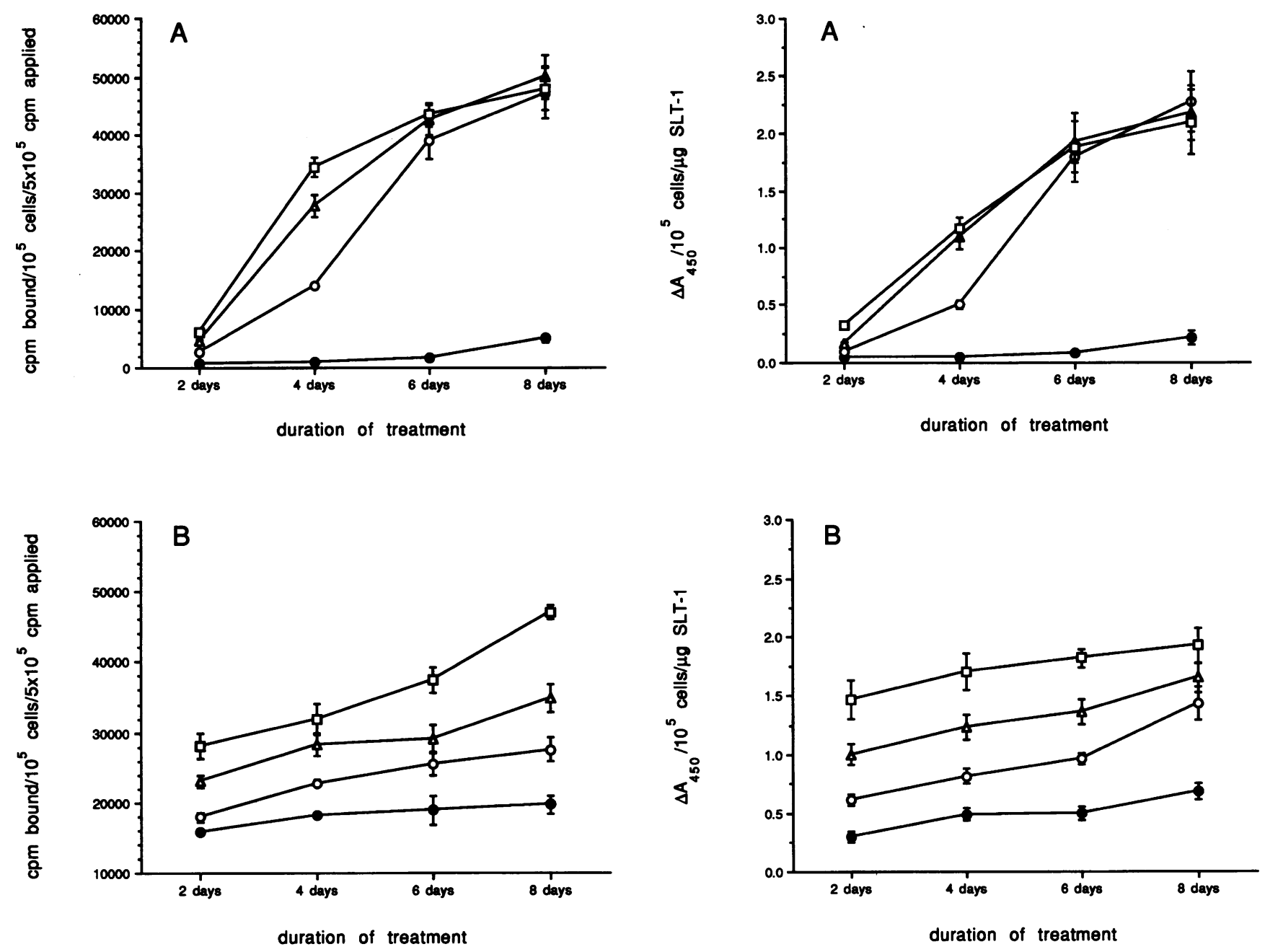

Figure 4. Effect of butyrate concentration and duration of exposure of CaCo-2A cells $(A)$ and HT-29 cells $(B)$ on the binding of ${ }^{125}$ I-labeled SLT-1 $\left(5 \times 10^{5} \mathrm{cpm}\right.$ per microtiter well). The black circles represent control cells (no butyrate exposure), open circles represent exposure to $0.5 \mathrm{mM}$ butyrate, open triangles show exposure to $1 \mathrm{mM}$ butyrate, and the open squares show exposure to $2 \mathrm{mM}$ butyrate. One standard deviation is indicated for each data point.

\section{Results}

Growth of cells in butyrate. Although the rate of cell division in cells exposed to $0.5-2.0 \mathrm{mM}$ butyrate diminished in a doserelated manner, whether examined by qualitative phase contrast microscopy of the monolayer or by quantitative cell counts over time, cells remained viable, and $\left[{ }^{3} \mathrm{H}\right]$ leucine incorporation into protein and uptake of ${ }^{3} \mathrm{H}$ - $\alpha$-amino-isobutyric acid were not reduced in butyrate-exposed compared with untreated control cells when adjusted to cell number (data not shown).

Effect of butyrate on enzyme markers of differentiation. Butyrate exposure resulted in an increase in alkaline phosphatase activity of all three cell lines in a dose- and duration of exposure-dependent manner (Fig. 1). When normalized to cell number and activity at time zero, $\mathrm{CaCo}-2 \mathrm{~A}$ cells were most responsive to butyrate, HT-29 cells were intermediate, and T84 cells were least responsive.

Butyrate exposure also resulted in increased sucrase (Fig. $2 A$ ) and lactase (Fig. 2 B) activities of CaCo-2A and HT29

Figure 5. Effect of butyrate concentration and duration of exposure of CaCo-2A cells $(A)$ and HT-29 cells $(B)$ on the binding of an applied dose of $200 \mathrm{ng}$ of SLT-1 per microtiter well. The black circles represent control cells (no butyrate exposure), open circles represent exposure to $0.5 \mathrm{mM}$ butyrate, open triangles show exposure to $1 \mathrm{mM}$ butyrate, and the open squares show exposure to $2 \mathrm{mM}$ butyrate. One standard deviation is indicated for each data point.

cells. No significant activity of either enzyme was detected in T-84 cells, even after $8 \mathrm{~d}$ of exposure to $2.0 \mathrm{mM}$ butyrate (data not shown).

Effect of butyrate treatment on sensitivity of cells to SLT1. Control CaCo-2A cells were insensitive to SLT-1 after $48 \mathrm{~h}$ of culture, but became increasingly sensitive thereafter (Fig. 3 $A$ ). HT-29 cells were moderately susceptible to the cytotoxic effects of SLT-1 $(1 \mu \mathrm{g} / \mathrm{ml})$ after $48 \mathrm{~h}$, and this did not change significantly over the next $6 \mathrm{~d}$ of study. Butyrate exposure markedly increased the cytotoxic activity of SLT-1 for CaCo-2A and, to a lesser extent, HT-29 cells (Fig. 3, $A$ and $B$ ) in a time- and butyrate dose-related manner. In contrast, T-84 cell monolayers remained resistant to toxin, regardless of the duration of exposure and concentration of butyrate added (data not shown). When HT-29 cells were switched from a glucose- to galactose-containing medium, which is known to induce differentiation in these cells (22), the 50\% cytotoxic dose of SLT-1 decreased from $2 \times 10^{2} \mu \mathrm{g} / \mathrm{ml}$ in glucose medium to $5 \times 10^{1}$ 
Table I. Effect of $8 d$ of Treatment with 2 mM Butyrate on Neutral Glycolipid Content of CaCo-2A and HT-29 Cells

\begin{tabular}{lccc}
\hline & & \multicolumn{2}{c}{ Glycolipid content } \\
\cline { 3 - 4 } Cell line & $\begin{array}{c}\text { Butyrate } \\
\text { exposure }\end{array}$ & Gb3 & Gb4 \\
\hline & & \multicolumn{2}{c}{ pmolmg cell protein } \\
CaCo-2A & - & $868 \pm 61$ & $213 \pm 41$ \\
CaCo-2A & + & $2410 \pm 25^{*}$ & $495 \pm 29^{*}$ \\
HT-29 & - & $318 \pm 204$ & $52 \pm 14$ \\
HT-29 & + & $1199 \pm 509^{\ddagger}$ & $7 \pm 14^{*}$ \\
\hline
\end{tabular}

${ }^{*} P<0.0001 ;{ }^{\ddagger} P=0.018$

and $2.3 \times 10^{-1} \mu \mathrm{g} / \mathrm{ml}$ after four and seven passages in galactose-containing medium, respectively.

Effect of butyrate treatment on toxin binding to cells. Consistent with the cytotoxicity data, untreated HT-29 cells bound significant amounts of ${ }^{125} \mathrm{I}$-toxin at $48 \mathrm{~h}$ of culture, with minimal change over the subsequent $6 \mathrm{~d}$, whereas CaCo-2A cells did not show a detectable increase until day 6 , increasing further at day 8 (Fig. $4, A$ and $B$ ). Butyrate exposure led to a doseand duration-dependent appearance of toxin-binding sites in both cell types in parallel to the change in cytotoxicity. Toxin binding to butyrate-treated T-84 cells also increased in a timeand dose-dependent manner, but to a much lower extent $(7,600$ cpm bound $/ 10^{5} \mathrm{~T}-84$ cells $/ 5 \times 10^{5} \mathrm{cpm}$ applied, compared with $48,000 \mathrm{cpm}$ bound $/ 10^{5} \mathrm{CaCo}-2 \mathrm{~A}$ cells $/ 5 \times 10^{5} \mathrm{cpm}$ applied in cells treated with $2.0 \mathrm{mM}$ butyrate for $8 \mathrm{~d}$ ). The EIA binding assay using unmodified toxin as the ligand confirmed these time- and dose-dependent effects of butyrate in $\mathrm{CaCo}-2 \mathrm{~A}$ and HT-29 cells (Fig. 5).

Effect of butyrate on glycolipid toxin receptors. To determine the basis for increased binding and toxicity of SLT-1 in CaCo-2A and HT-29 cells, we measured the levels of neutral glycolipid receptors for Shiga family toxins, including Gb3 and $\mathrm{Gb} 4$, in duplicate analyses of two separate experiments (Table I). After $8 \mathrm{~d}$ of exposure to $2 \mathrm{mM}$ butyrate, both cell types expressed significantly more $\mathrm{Gb} 3$ than untreated cells. The amount of $\mathrm{Gb} 4$, the receptor for the SLT-2 variant toxin SLT$2 \mathrm{e}$, also significantly increased in CaCo-2A cells, but decreased in HT-29 cells. Untreated T-84 cell monolayers did not contain $\mathrm{Gb} 3$ nor Gb4 and there was no detectable induction after $8 \mathrm{~d}$ of incubation in the presence of butyrate (data not shown).

Effect of actinomycin $D$ and cycloheximide on butyrateinduced toxin binding. To examine whether butyrate-induced $\mathrm{Gb} 3$ expression in CaCo-2A cells was mediated at the transcriptional level, we pretreated $\mathrm{CaCo}-2 \mathrm{~A}$ cells with either actinomycin D or cycloheximide for $24 \mathrm{~h}$ before exposure to butyrate. We assessed toxin binding, expressed as a percentage of the value in the 24-h no butyrate control monolayer in the absence of either inhibitor, rather than SLT-1-mediated cytotoxicity, because both inhibitors themselves block leucine incorporation into protein. In control cells, exposure to actinomycin D clearly blocked the increase in toxin binding that occurs by $72 \mathrm{~h}$ of growth of the monolayer, with rebound recovery at $144 \mathrm{~h}$ (Table II). Cycloheximide was even more effective, and a sharp reduction in toxin binding was already present by $24 \mathrm{~h}$, which persisted at $72 \mathrm{~h}$ but dissipated by $144 \mathrm{~h}$. Similar but more pronounced effects were found when cells preincubated with inhib-
Table II. Effect of Actinomycin D and Cycloheximide on Butyrate-induced SLT-1 Binding to CaCo-2A Cells

\begin{tabular}{|c|c|c|c|}
\hline \multirow[b]{3}{*}{ Inhibitor } & \multicolumn{3}{|c|}{${ }^{125}$ I-SLT-1 binding to $\mathrm{CaCo}-2 \mathrm{~A}$ cells } \\
\hline & \multicolumn{3}{|c|}{ Duration of incubation } \\
\hline & $24 \mathrm{~h}$ & $72 \mathrm{~h}$ & $144 \mathrm{~h}$ \\
\hline & \multicolumn{3}{|c|}{$\%$ of control at $24 \mathrm{~h}$} \\
\hline \multicolumn{4}{|l|}{ No butyrate } \\
\hline No inhibitor & $100.0 \pm 6.8$ & $120.8 \pm 11.0^{*}$ & $142.7 \pm 12.2 *$ \\
\hline Actinomycin D & $113.5 \pm 10.0^{\ddagger}$ & $87.0 \pm 8.2^{8}$ & $171.2 \pm 15.6^{\ddagger}$ \\
\hline Cycloheximide & $59.4 \pm 3.0^{8}$ & $83.3 \pm 3.7^{8}$ & $136.0 \pm 11.9^{\ddagger}$ \\
\hline \multicolumn{4}{|l|}{ Butyrate, $24 \mathrm{~h}$} \\
\hline No inhibitor & $170.7 \pm 10.5$ & $313.7 \pm 26.2 *$ & $388.0 \pm 17.7 *$ \\
\hline Actinomycin D & $111.8 \pm 4.6^{8}$ & $166.8 \pm 12.6^{8}$ & $411.5 \pm 18.1^{\ddagger}$ \\
\hline Cycloheximide & $73.3 \pm 4.0^{8}$ & $81.4 \pm 6.5^{\S}$ & $342.7 \pm 21.2^{\ddagger}$ \\
\hline
\end{tabular}

${ }^{*} P<0.01$ compared with value at $24 \mathrm{~h}$, no inhibitor. ${ }^{\ddagger}$ Not significant compared with no inhibitor at the same time point.

${ }^{8} P<0.01$ compared with no inhibitor at the same time point.

These data are a representative experiment (from three separate experiments) and the results reported are the mean \pm 1 SD from three separate microtiter plate wells.

itors were then exposed to butyrate (Table II). In this case, both actinomycin $\mathrm{D}$ and cycloheximide reduced the butyratestimulated binding at 24 and $72 \mathrm{~h}$. The subsequent recovery from actinomycin D or cycloheximide was similar in both butyrate-treated and untreated cells.

Binding of FITC-SLT-1 B subunit to cell monolayers. To visualize binding to individual monolayer cells, we coupled FITC directly to recombinant SLT-1 B subunit and used this reagent to assess binding by fluorescence microscopy. There was a butyrate dose- and duration-dependent increase in the number of $\mathrm{CaCo}-2 \mathrm{~A}$ and HT-29 cells that fluoresced, consistent with the results described above. Fig. 6 shows the binding of FITC-SLT-1 B subunit to control (medium alone) and experimental ( $2 \mathrm{mM}$ butyrate for $8 \mathrm{~d}$ ) CaCo-2A, HT-29, and T-84 cells. The increase in fluorescence in CaCo-2A (Fig. 6, $A$ and $B$ ) and HT29 (Fig. 6, $C$ and $D$ ) cells was due to an increase in the proportion of labeled cells in the monolayer binding FITC-toxin. Although we detected no effect of butyrate on total Gb3 content or cytotoxicity of T-84 cells, and the vast majority (>95\%) of cells did not fluoresce, butyrate-treated T-84 cell monolayers developed occasional small foci of cells that bound FITC-SLT-1 B subunit.

To determine if toxin binding and nonbinding $\mathrm{CaCo}-2 \mathrm{~A}$ cell populations detected by FITC-SLT-1 B differed in their expression of differentiation markers, we separated these two populations by FACS ${ }^{\circledR}$ sorting and assayed each separately for alkaline phosphatase activity. $\mathrm{CaCo}-2 \mathrm{~A}$ cells that bound FITCSLT-1 B were alkaline phosphatase positive, with an increase in $A_{405}$ of $19.2 / 10^{6}$ cells $/ \mathrm{h}$, whereas the negative cell population exhibited no detectable change in $\mathrm{A}_{405}$ from background.

\section{Discussion}

The possibility that the enterotoxic activity of Shiga family toxins is due to a selective effect on differentiated cells of the 

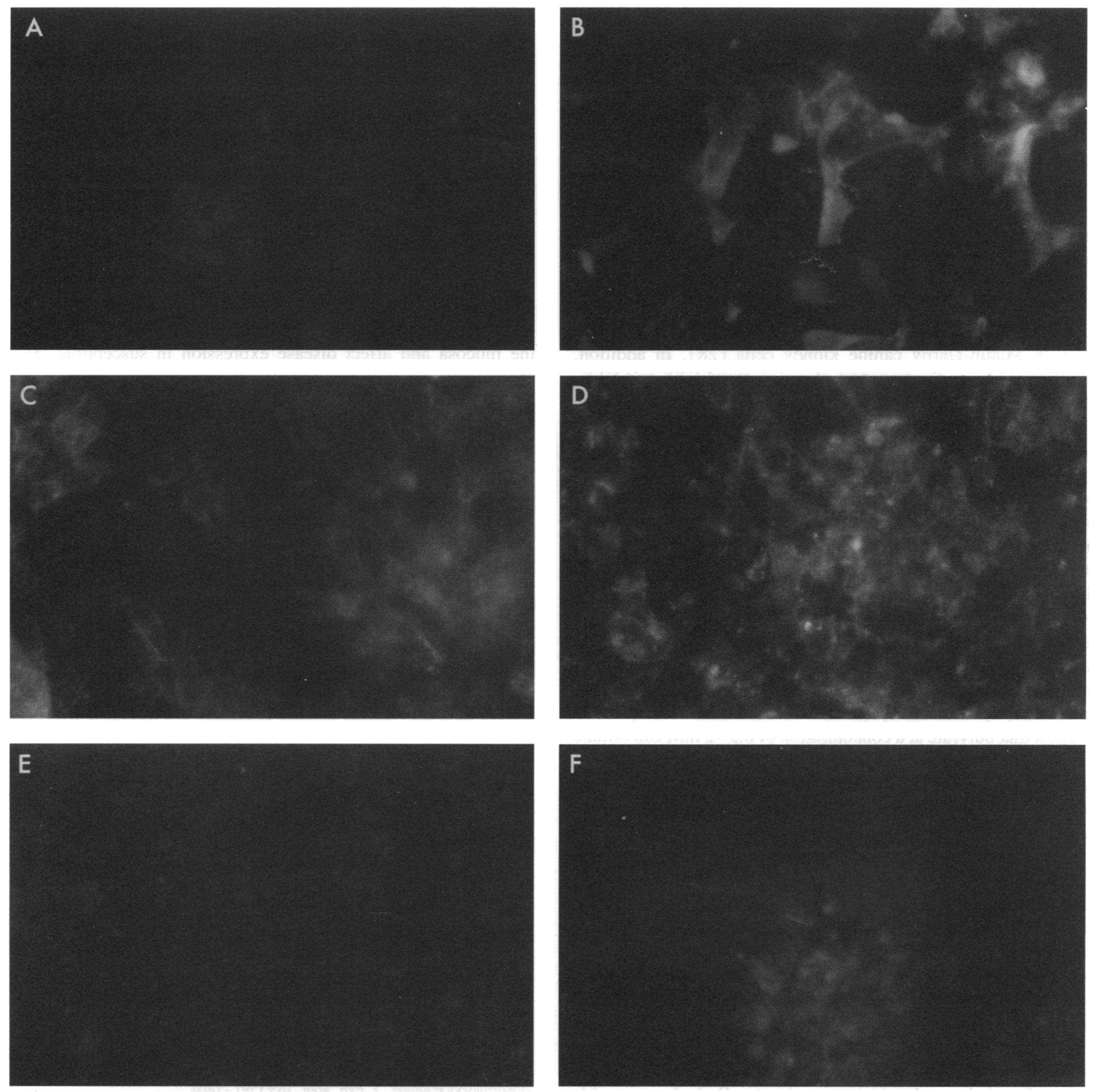

Figure 6. Fluorescence photomicrographs of confluent CaCo-2A, HT-29, and T-84 cells exposed to $8 \mathrm{~d}$ of culture in the absence of butyrate ( $A$, $C$, and $E$, respectively) or after $8 \mathrm{~d}$ of exposure to $2 \mathrm{mM}$ butyrate $(B, D$, and $F$, respectively). Cells were fixed with $4 \%$ paraformaldehyde and incubated with FITC-labeled SLT-1 B for $1 \mathrm{~h}$ as described in Methods. Fluorescence of bound FITC-B subunit was visualized with a Nikon Labophot microscope as described in Methods. $\times 400$.

small intestine was first suggested by Kandel et al. (8). These investigators eluted cells from rabbit small intestine along a villus-to-crypt gradient and reported that Gb3, the SLT-1 receptor, was present only in the villus cells, and only villus cells showed toxin-mediated protein synthesis inhibition. These effects were consistent with the observed reduction in mucosal to serosal sodium flux, without alteration in serosal to mucosal chloride flux, in toxin-treated jejunal mucosa mounted in Ussing chambers. Mobassaleh et al. (23) subsequently reported that while infant rabbits were refractory to the fluid secretory effect of STX in ligated small bowel loops in the first 2 wk of life, the fluid response progressively increased after day 16 as Gb3 content increased from very low levels to adult levels by the fourth week of life (24). These data suggested that sensitivity of intestinal epithelial cells to the Shiga family of toxins is both a property of differentiated mature villus cells and, at least in the rabbit, developmentally regulated.

We hypothesized that, during the course of epithelial cell migration up the villus, differentiation signals for enterocytes also affect the enzymes responsible for synthesis of the toxin 
receptor. We chose to test this hypothesis using human cell lines capable of expressing small bowel villus (CaCo-2A, HT29) $(22,25)$ or crypt (T-84) (26) cell characteristics during differentiation in vitro, which is induced after $\mathrm{CaCo}-2 \mathrm{~A}$ cells grow to confluency (25) or HT-29 cells are deprived of glucose by switching to a high galactose medium, which results in clones resembling the different cell types found in the small intestine (22). We chose to study the effect of butyrate, a well known inducer of cell differentiation in vitro (11-13), which leads to the expression of villus-like enzymatic and absorptive activities in CaCo-2 and HT-29 cells $(10,14)$. Butyrate can also alter expression of both glycolipid (27) and glycoprotein (11) receptors in certain cells and has been reported to increase expression of STX-binding sites and enhance cytotoxicity of STX in Madin-Darby canine kidney cells (28). In addition, butyrate enhances the transport of endocytosed STX and STXB subunit to the Golgi region and, in retrograde fashion, to the endoplasmic reticulum, in A431 human epidermoid carcinoma cells, increasing sensitivity to STX (29).

The present studies demonstrate that CaCo-2A and HT-29 cells become more responsive to the effects of SLT-1 as they mature. Both cell lines expressed increased villus-like brush border enzyme activities (9), including alkaline phosphatase, sucrase, and lactase, after coincubation with butyrate for $8 \mathrm{~d}$, depending on the dose of butyrate used and the length of exposure. Although butyrate treatment of the crypt-like T-84 cells increased alkaline phosphatase activity in a similar, but less marked, fashion, neither disaccharidase activity was detected at any time during the 8-d experiment, and the monolayers remained resistant to the cytotoxic effects of SLT-1. These data suggest that butyrate at a concentration of $0.5-2 \mathrm{mM}$ can initiate differentiation of T-84 cells, but the process stops short of more terminal differentiation and expression of disaccharidases. Possibly higher concentrations of butyrate or additional signals are required to drive the further maturation of $\mathrm{T}-84$ cells.

As expected, butyrate exposure slowed the rate of division of all three cell lines $(30,31)$ but did not affect amino acid uptake or reduce cellular protein synthesis. The effects of butyrate on the differentiation markers studied and the cytotoxic response to SLT-1 in CaCo-2A and HT-29 cells were similar but more marked than the effect of other maturational stimuli, such as incubation after confluency of $\mathrm{CaCo}-2 \mathrm{~A}$ cells or glucose deprivation of HT-29 cells. The correlation of differentiation and the appearance of toxin-binding sites was clearly shown when we FACS ${ }^{\circledR}$ sorted CaCo-2A cells binding FITC-SLT-1 $B$ and found that only receptor-positive cells had measurable alkaline phosphatase activity.

Butyrate induces mRNA for many proteins in differentiating cells (11), apparently by histone deacetylation (32) and/or DNA hypermethylation (33), which play a role in regulating gene expression. The ability of both actinomycin $\mathrm{D}$ and cycloheximide to block butyrate induction of $\mathrm{Gb} 3$ in $\mathrm{CaCo}-2 \mathrm{~A}$ cells strongly suggests that butyrate is acting at the transcriptional level. Likely targets for this effect are the UDP-galactose/lactosylceramide galactosyltransferase involved in the biosynthetic pathway for $\mathrm{Gb} 3$ and/or $\alpha$-galactosidase, a major degradative enzyme for $\mathrm{Gb} 3$ (34).

Finally, these experiments raise the question of whether butyrate plays a role in situ in intestinal cell differentiation in vivo. Interestingly, butyrate occurs naturally in normal human colon as a by-product of metabolism of unabsorbed starch and nonstarch polysaccharides by the colonic bacterial flora and is used as an energy source by colonocytes (35). Fecal levels of butyrate in normal humans may be as high as $20 \mathrm{mM}$ (36), which exceeds the maximum concentration used in these studies by 10 -fold. When butyrate is absent, as in surgical colonic bypass procedures or after antibiotic therapy which destroys the intestinal mucosal flora, a syndrome known as diversion colitis may ensue, which is reversible by administration of butyrate (37). In addition, colitis may be induced in laboratory animals by short exposure to very high doses of butyrate given rectally $(38,39)$. Thus, it is clear that butyrate is normally produced in vivo and can affect intestinal epithelial cells that are exposed to it in vivo. It is plausible to propose that butyrate regulates differentiation of host colonic cells in situ and that manipulation of butyrate may alter the interaction of STX family toxins with the mucosa and affect disease expression in susceptible host species.

\section{Acknowledgments}

We thank Dr. Anne V. Kane for preparing and purifying the SLT-1 used in these studies in the Gastroenterology Research Center Core Microbiology Laboratory under National Institutes of Health grant DK34928.

These studies were supported by grants from the National Institutes of Health (AI-16242 to G. T. Keusch, AI-20325 to A. Donohue-Rolfe, and DK-39120 to M. Mobassaleh), a Gastroenterology Research Center Grant (DK-34928) and a grant from the Rockefeller Foundation under the Health Sciences for the Tropics Program (G. T. Keusch and K. A. Balasubramanian). Dr. Acheson was supported during a portion of these studies by an Infectious Diseases Training Grant, T32 AI-07329, to G. T. Keusch from the National Institute of Allergy and Infectious Diseases.

\section{References}

1. Acheson, D. W. K., A. Donohue-Rolfe, and G. T. Keusch. 1991. The family of Shiga and Shiga-like toxins. In Sourcebook of Bacterial Protein Toxins. J. E. Alouf and J. H. Freer, editors. Academic Press, Ltd., London. 415-433.

2. O'Brien, A. D., and R. Holmes. 1987. Shiga and Shiga-like toxins. Microbiol. Rev. 51:206-220.

3. Schmidt, H., M. Montag, J. Bockemuhl, J. Heeseman, and H. Karch. 1993. Shiga-like toxin II-related cytotoxins in Citrobacter freundii strains from humans and beef samples. Infect. Immun. 61:534-543.

4. Endo, Y., K. Tsurugi, T. Yutsudo, Y. Takeda, T. Ogasawara, and K. Igarashi. 1988. Site of action of a Vero toxin (VT2) from Escherichia coli 0157:H7 and of Shiga toxin on eukaryotic ribosomes. RNA $N$-glycosidase activity of the toxin. Eur. J. Biochem. 171:45-50.

5. Jacewicz, M., H. Clausen, E. Nudelman, A. Donohue-Rolfe, and G. T. Keusch. 1986. Pathogenesis of Shigella diarrhea. XI. Isolation of a shigella toxinbinding glycolipid from rabbit jejunum and HeLa cells and its identification as globotriaosylceramide. J. Exp. Med. 163:1391-1404.

6. Lindberg, A. A., J. E. Brown, N. Strömberg, M. Westling-Ryd, J. E. Schultz, and K. A. Karlsson. 1987. Identification of the carbohydrate receptor for Shiga toxin produced by Shigella dysenteriae type 1. J. Biol. Chem. 262:1779-1785.

7. DeGrandis, S., H. Law, J. Brunton, C. Gyles, and C. A. Lingwood. 1989. Globotetraosylceramide is recognized by the pig edema disease toxin. J. Biol. Chem. 264:12520-12525.

8. Kandel, G., A. Donohue-Rolfe, M. Donowitz, and G. T. Keusch. 1989. Pathogenesis of Shigella diarrhea. XIV. Selective targeting of Shiga toxin to villus cells of rabbit jejunum explains the effect of toxin on intestinal electrolyte transport. J. Clin. Invest. 84:1509-1517.

9. Matusumoto, H., R. H. Erickson, J. R. Gum, M. Yoshioka, E. Gum, and Y. S. Kim. 1990. Biosynthesis of alkaline phosphatase during differentiation of the human colon cancer cell line Caco-2. Gastroenterology. 98:1199-1207.

10. Augeron, C., and C. L. Laboisse. 1984. Emergence of permanently differentiated cell clones in a human colonic cell line in culture after treatment with sodium butyrate. Cancer Res. 44:3961-3969.

11. Nathan, D. F., S. R. Burkhart, and M. J. Morin. 1990. Increased cell surface EGF receptor expression during the butyrate-induced differentiation of human HCT-116 colon tumor cell clones. Exp. Cell Res. 190:76-84.

12. Leder, A., and P. Leder. 1975. Butyric acid, a potent inducer of erythroid differentiation in cultured erythroleukemic cells. Cell. 5:319-322. 
13. Toscani, A., D. R. Soprano, and K. J. Soprano. 1990. Sodium butyrate in combination with insulin or dexamethasone can terminally differentiate actively proliferating Swiss 3T3 cells into adipocytes. J. Biol. Chem. 265:5722-5730.

14. Chung, Y. S., I. S. Song, R. Erickson, M. H. Sleisenger, and Y. S. Kim 1985. Effect of growth and sodium butyrate on brush border membrane-associated hydrolases in human colorectal cancer cell lines. Cancer Res. 45:2976-2982.

15. Boerner, P., and M. H. Saier, Jr. 1988. Effects of 5-azacytidine, sodium butyrate, and phorbol esters on amino acid transport system $A$ in a kidney epithelial cell line, MDCK: evidence for multiple mechanisms of regulation. J. Cell. Physiol. 137:117-124.

16. Donohue-Rolfe, A., D. W. K. Acheson, A. V. Kane, and G. T. Keusch. 1989. Purification of Shiga and Shiga-like toxins I and II by receptor analog affinity chromatography with immobilized P1 glycoprotein and the production of cross-reactive monoclonal antibodies. Infect. Immun. 57:3888-3893.

7. Donohue-Rolfe, A. G. T. Keusch, C. Edson, D. Thorley-Lawson, and M. Jacewicz. 1984. Pathogenesis of Shigella diarrhea. IX. Simplified high yield purification of Shigella toxin and characterization of subunit composition and function by the use of subunit-specific monoclonal and polyclonal antibodies. $J$. Exp. Med. 160:1767-1781.

18. Acheson, D. W. K., S. B. Calderwood, S. A. Boyko, L. L. Lincicome, A. V. Kane, A. Donohue-Rolfe, and G. T. Keusch. 1993. Comparison of Shiga like toxin I B-subunit expression and localization in Escherichia coli and Vibrio cholerae by using trc or iron-regulated promoter systems. Infect. Immun. 61:10981104.

19. Jacewicz, M., H. A. Feldman, A. Donohue-Rolfe, K. A. Balasubramanian, and G. T. Keusch. 1989. Pathogenesis of Shigella diarrhea. XIV. Analysis of Shiga toxin receptors on cloned HeLa cells. J. Infect. Dis. 159:881-889.

20. Messer, M., and A. Dahlqvist. 1966. A one-step ultramicro method for the assay of intestinal disaccharidases. Anal. Biochem. 14:376-392.

21. Jacewicz, M. S., M. Mobassaleh, S. K. Gross, K. A. Balasubramanian, P. F. Daniel, S. Raghavan, R. McCluer, and G. T. Keusch. 1994. Pathogenesis of Shigella diarrhea. XVII. A mammalian cell membrane glycolipid, Gb3, is required but not sufficient to confer sensitivity to Shiga toxin. J. Infect. Dis. 169:538546.

2. Pinto, M., M. D. Appay, P. Simon-Assman, G. Chevalier, N. Dracopoli, J. Hogh, and A. Zweibaum. 1982. Enterocytic differentiation of cultured human colon cells by replacement of glucose by galactose in the medium. Biol. Cell. 44:193-196.

23. Mobassaleh, M., A. Donohue-Rolfe, M. Jacewicz, R. J. Grand, and G. T. Keusch. 1988. Pathogenesis of Shigella diarrhea: evidence for a developmentally regulated glycolipid receptor for shigella toxin involved in the fluid secretory response of rabbit small intestine. J. Infect. Dis. 157:1023-1031.

24. Mobassaleh, M., S. K. Gross, R. H. McCluer, A. Donohue-Rolfe, and G. T. Keusch. 1989. Quantitation of the rabbit intestinal glycolipid receptor for Shiga toxin. Gastroenterology. 97:384-391.
25. Pinto, M., S. Robine-Leon, M. Appay, M. Kedinger, E. Triadou, E. Dussaulx, B. Lacroix, P. Simon-Assman, K. Haffen, J. Fogh, and A. Zweibaum. 1983. Enterocyte-like differentiation of the human colon carcinoma cell line, $\mathrm{CaCo}-2$, in culture. Biol. Cell. 47:323-330.

26. Dharmasathaphorn, K., J. A. McRoberts, K. G. Mandel, L. D. Tisdale, and H. Masui. 1984. A human colonic tumor cell line that maintains vectoral electrolyte transport. Am. J. Physiol. 246:G204-G208.

27. Heneberry, R. C., and P. H. Fishman. 1976. Morphological and biochemical differentiation in HeLa cells. Effects of cycloheximide on butyrate-induced process formation and ganglioside metabolism. Exp. Cell Res. 103:55-62.

28. Sandvig, K., K. Prydz, M. Ryd, and B. van Deurs. 1991. Endocytosis and intracellular transport of the glycolipid-binding ligand Shiga toxin in polarized MDCK cells. J. Cell Biol. 113:553-562.

29. Sandvig, K., M. Ryd, O. Garred, E. Schweda, P. K. Holm, and B. van Deurs. 1994. Retrograde transport from the Golgi complex to the ER of both Shiga toxin and the nontoxic Shiga B-fragment is regulated by butyric acid and cAMP. J. Cell Biol. 126:53-64.

30. Dexter, D. L., S. F. Konieczny, J. B. Lawrence, M. Shaffer, P. Mitchell, and J. R. Coleman. 1981. Induction by butyrate of differentiated properties in cloned murine rhabdosarcoma cells. Differentiation. 18:115-122.

31. Gabius, S., N. Yamazaki, W. Hanewacker, and H.-J. Gabius. 1990. Regulation of distribution, amount and ligand affinity of sugar receptors in human colon carcinoma cells by treatment with sodium butyrate, retinoic acid and phorbol ester. Anticancer Res. 10:1005-1012.

32. Boffa, L. C., G. Vidali, R. S. Mann, and V. G. Allfrey. 1978. Suppression of histone deacetylation in vivo and in vitro by sodium butyrate. J. Biol. Chem. 253:3364-3366.

33. Parker, M. I. J. B de Haan, and W. Gevers. 1986. DNA hypermethylation in sodium butyrate-treated WI-38 fibroblasts. J. Biol. Chem. 261:2786-2790.

34. Mobassaleh, M., O. Koul, M. Mishra, R. H. McCluer, and G. T. Keusch. 1994. Developmentally regulated $\mathrm{Gb}_{3}$ galactosyltransferase and $\alpha$-galactosidase determine Shiga toxin receptors in intestine. Am. J. Physiol. 267:G618-G624.

35. Scheppach, W. 1994. Effects of short chain fatty acids on gut morphology and function. Gut. 35(Suppl. 1):S35-S38.

36. Cummings, J. H., E. W. Pomare, W. J. Branch, C. P. E. Naylor, and G. T. MacFarlane. 1987. Short chain fatty acids in human large intestine, portal, hepatic and venous blood. Gut. 28:1221-1227.

37. Agarwal, V. P., and E. M. Schimmel. 1989. Diversion colitis: a nutritional deficiency syndrome? Nutr. Rev. 47:257-261.

38. Scheppach, W., H. Sommer, T. Kirchner, G. M. Paganelli, P. Bartram, S. Christl, F. Richter, G. Dusel, and H. Kasper. 1992. Effect of butyrate enemas on the colonic mucosa in distal ulcerative colitis. Gastroenterology. 103:51-56.

39. McCafferty, D. M., and I. J. Zeitlin. 1989. Short chain fatty acid-induced colitis in mice. Int. J. Tissue React. 11:165-168. 